\title{
Older and Younger Coversand in southern Jutland (Denmark)
}

\author{
ELSE KOLSTRUP AND JEPPE BENDER JØRGENSEN
}

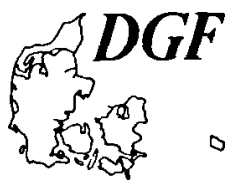

Kolstrup, E. \& Jørgensen, J. B.: Older and Younger Coversand in southern Jutland (Denmark). Bull. geol. Soc. Denmark, vol. 30, pp. 71-77, Copenhagen, September 1st, 1982.

https://doi.org/10.37570/bgsd-1981-30-07

\begin{abstract}
During trenching for a gas pipeline in southern Jutland extensive aeolian deposits were observed. This note describes their appearance, texture, and grain-size distributions, and it is concluded that deposits of both Older and Younger Coversands are present.

The lithostratigraphical sequence is identical to that in the coversand areas in The Netherlands, Belgium, and northern Germany.
\end{abstract}

Else Kolstrup, Danmarks geologiske Undersøgelse, Thoravej 31, DK-2400 København NV, Denmark. Jeppe Bender Jørgensen, Geologisk Centralinstitut, Øster Voldgade 10, DK-1350 København K, Denmark. November 22nd, 1981.

During trenching for a gas pipeline in southern Jutland a continuous trench, two meters deep, exposed several kilometers of sediments. In order to obtain stable walls in the trench, slanting slopes were dug. As a consequence it was necessary to clean profiles by hand in order to study the sediments. Since the trench was usually filled in after only a few hours, it was often difficult to obtain good photographs because the time was too short to permit drying of the face and the associated accentuation of the layering in the profiles.

In spite of these difficulties it was possible to obtain information concerning structures, grainsize distributions, and transitions between sedimentary beds. From this evidence it is concluded that the sediments in the southern $13 \mathrm{~km}$ of the pipeline trench (fig. 1) are dominated by two characteristic sedimentary units, a lower and an upper one. In the following, the two units are described, and the lithostratigraphic sequence is outlined.

\section{Lower unit}

In the section in southern Jutland (indicated in figure 1) the lower unit rests upon a layer of polished and faceted pebbles and small stones which in turn rests upon a strongly involuted sequence of sand and gravel. Upwards the lower unit passes gradually into either the upper unit (figs 2 and 3 ) or there may be a fine-grained layer separating the two units (figs 4 and 5). This separating layer sometimes possesses faint mottling and is dominated by particles ranging from $63 \mu \mathrm{m}$ to $105 \mu \mathrm{m}$.

The lower unit consists almost invariably of

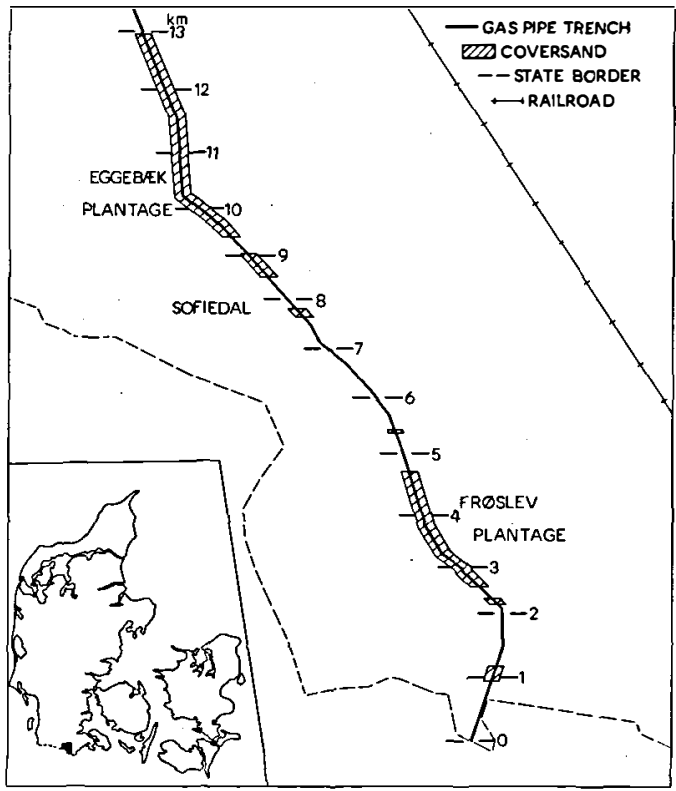

Fig. 1. Location of the southern $13 \mathrm{~km}$ of the gas pipeline trench in Jutland with coversand occurrences indicated. 


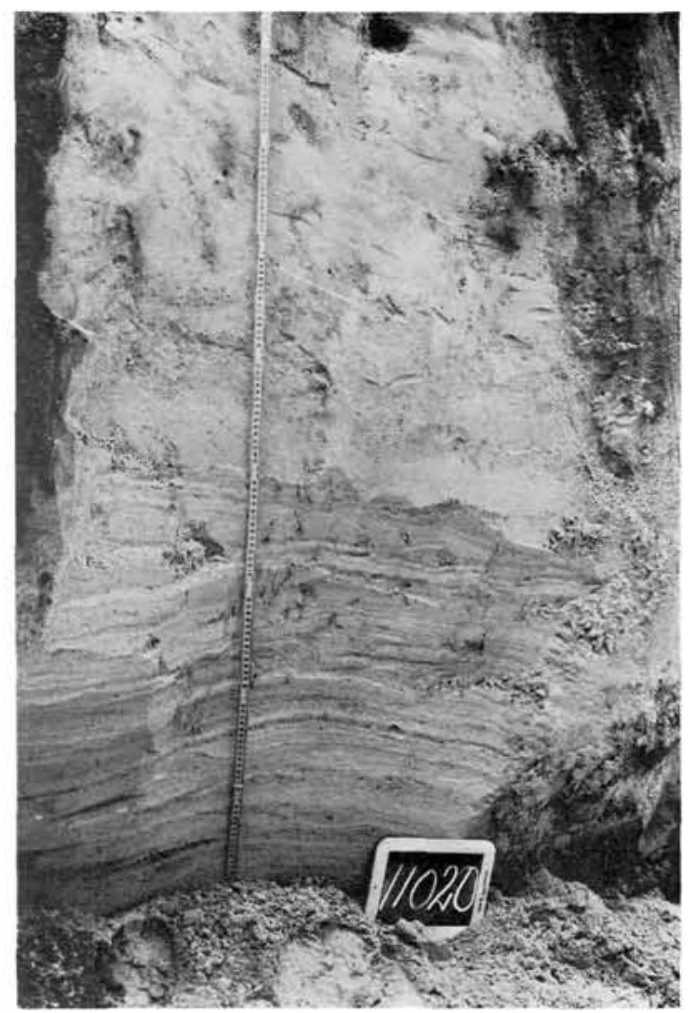

Fig. 2. Km 11.020. Coarsely developed Older Coversand with a gradual transition upwards to Younger Coversand without structures. The visible part of the ruler is $140 \mathrm{~cm}$ long.

horizontal laminae which alternate between very fine sand and fine to medium sand (figs 4 and 5). The laminae range in thickness from a few millimeters to a few centimeters. Fig. 6 (B, C, D, E, and $F$ ) shows typical grain-size histograms from this type of deposit. However, field study of the grain-size of the individual laminae revealed two size-classes, usually of 63-105 $\mu \mathrm{m}$ and $125-250$ $\mu \mathrm{m}$ respectively. Since samples for grain-size analysis contain both the very fine and fine sand laminae, only one maximum is normally found. Usually almost equal amounts of the two sizeclasses were encountered. However, in some parts of the trench, the fine fraction was dominant. In such profiles decimeter thick layers of very fine sand to silt (sandloess: Woldstedt \& Duphorn 1974: 43) were sometimes present (fig. 6: G). In other parts of the trench the coarser fraction prevailed (fig. 2).

The individual laminae within the lower unit can be followed laterally over several meters and the layers are usually undisturbed (figs 2, 4, and $5)$. In parts of the trench undulations of one to five $\mathrm{cm}$ in vertical extent were observed (fig. 3).

The individual grains of this type of deposit are well-rounded to sub-rounded, and polished (fig. 7) and this, together with the good sorting of the sediment and the wind-polished pebbles at the base, points to an aeolian origin.

Although the undisturbed lower unit in southern Denmark is locally more than two meters thick the thickness is usually between 50 and 100 $\mathrm{cm}$.

The appearance and composition of this unit as well as its lithostratigraphic position (see below) is identical to that of the Older Coversand II described from The Netherlands (compare e.g. van der Hammen 1951; Dücker \& Maarleveld 1957; Wijmstra, Schreve-Brinkman \& de Vin 1971). In the following, therefore, this unit is designated Older Coversand.

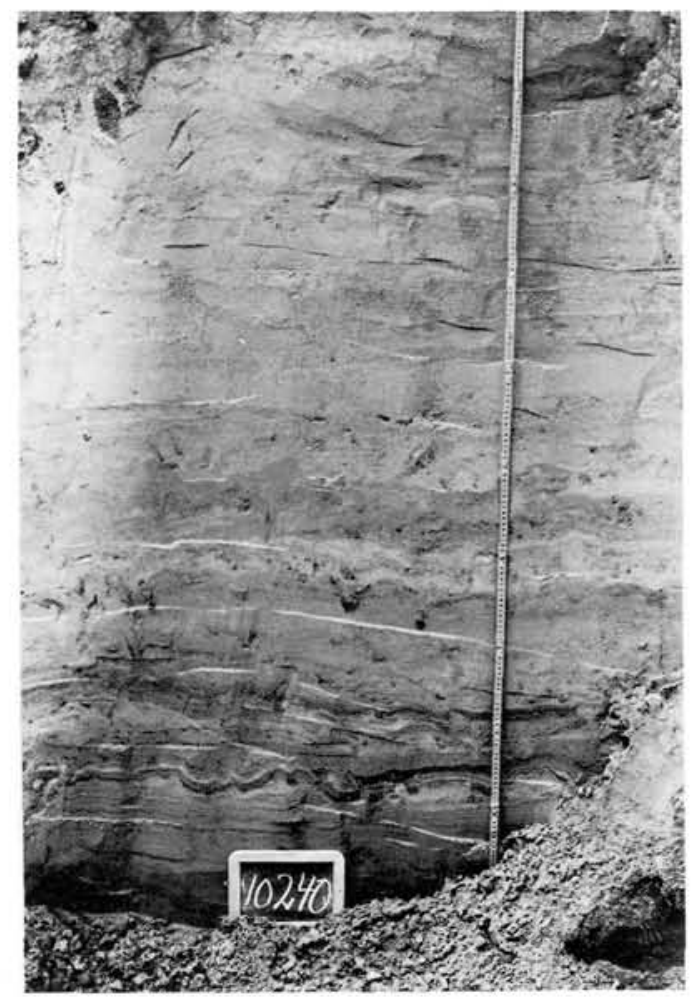

Fig. 3. Km 10.240. Older Coversand with shallow undulations of some of the laminae overlain by Younger Coversand with indistinct layering. The visible part of the ruler is $150 \mathrm{~cm}$ long. 


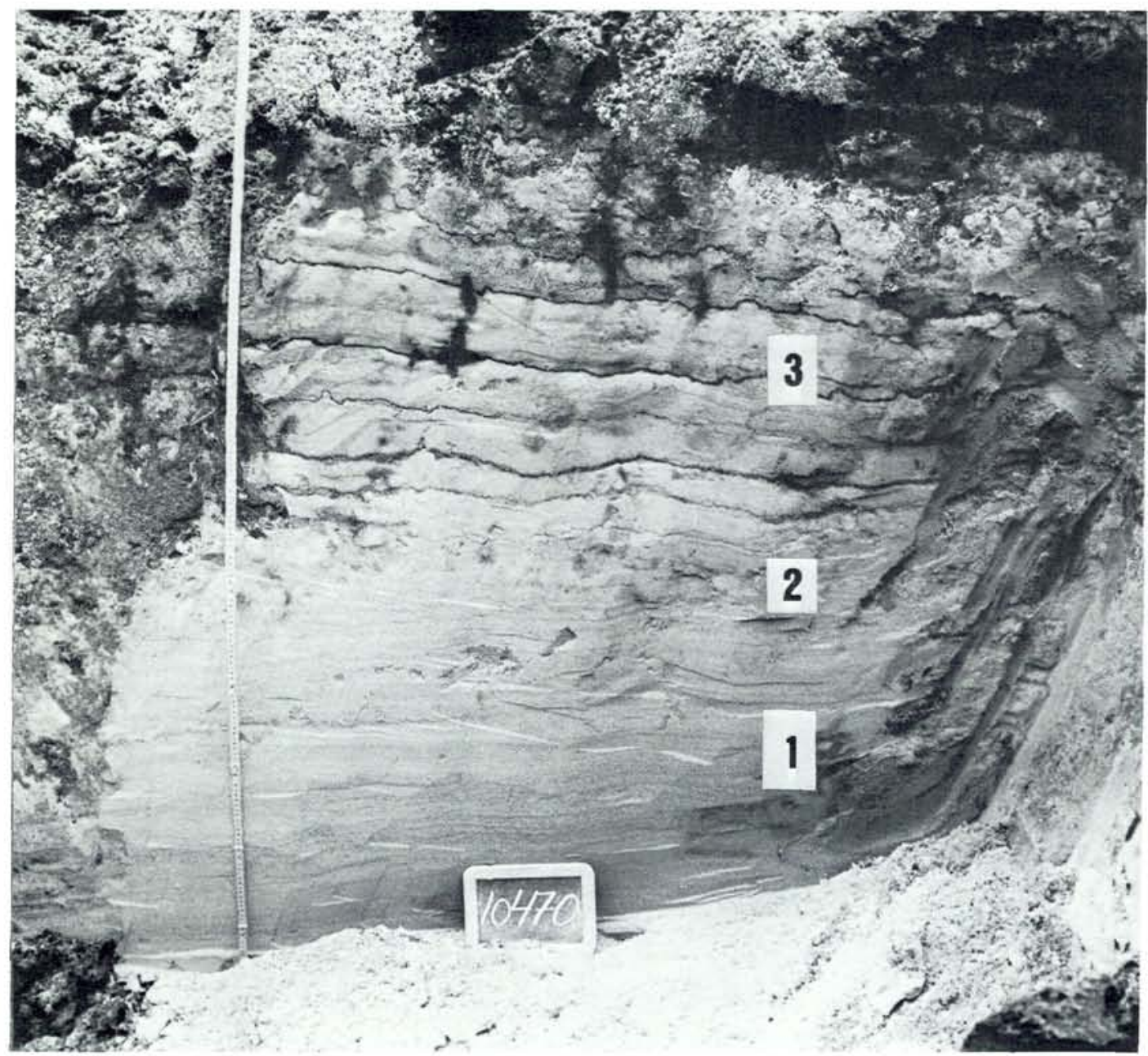

Fig. 4. Km 10,470. 1) Undisturbed Older Coversand, 2) Bioturbated zone, and 3) Younger Coversand with iron-manganese precipitate following the layering of the sediment. The visible part of the ruler is $170 \mathrm{~cm}$ long.

\section{Upper unit}

The upper unit rests upon the Older Coversand or the bioturbated zone. Its upper part is situated in or just below the top soil and therefore the layering is often disturbed (fig. 3) or has completely disappeared (Fig. 2).

The upper unit also has a horizontal layering of individual laminae which range from a few millimeters to a few centimeters in thickness (figs 4 and 5). However, in the upper unit very fine sand laminae are lacking and it is normally slightly coarser than the Older Coversand. In the field the dominant grain-size class of the upper unit was usually found to be $125-250 \mu \mathrm{m}$ (fig. 6: A). Locally the grain-size of individual laminae within the upper unit may be coarser (1-2 mm).

As with the Older Coversand, the sand-grains in the upper unit are well-rounded to subrounded and this, together with the good sorting makes an aeolian origin probable. The greatest thickness of the upper unit recorded in southern Jutland is approximately $1.5 \mathrm{~m}$.

Within the upper unit a bioturbated zone is sometimes found (fig. 5) suggesting incipient soil development during deposition. 


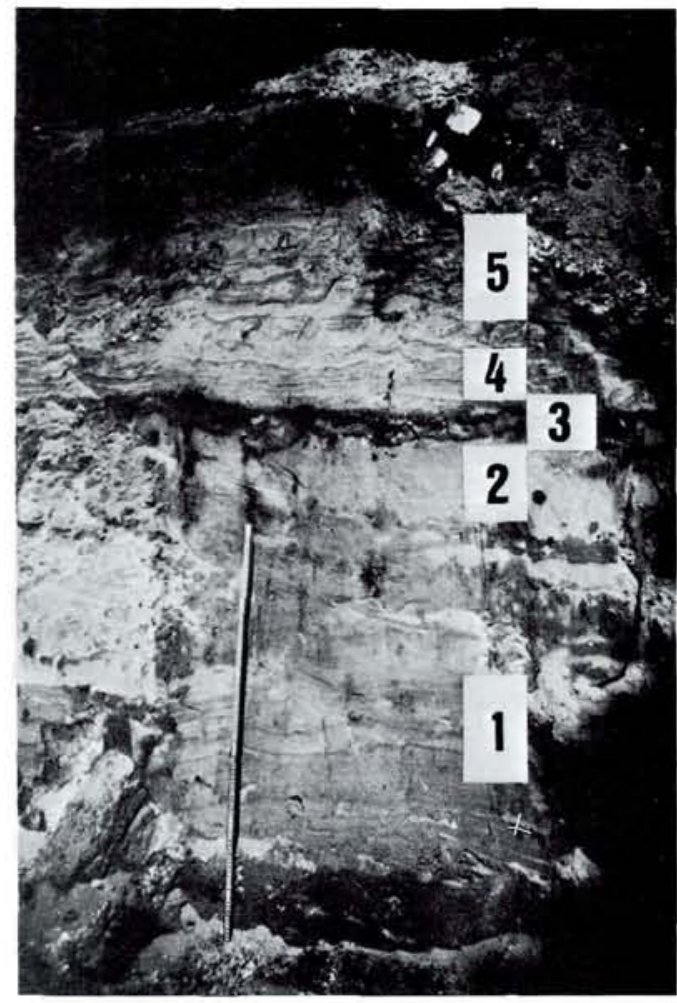

Fig. 5. Km 2.800. 1) Undisturbed Older Coversand, 2) Older Coversand without structures, 3) very fine sand to loam, 4) undisturbed Younger Coversand, and 5) bioturbated Younger Coversand. The visible part of the ruler is $95 \mathrm{~cm}$ long.

Also this unit is identical to a unit known from The Netherlands, namely the Younger Coversand (compare e.g. van der Hammen 1951; Dücker \& Maarleveld 1957; Wijmstra et al. 1971).

\section{Land surface morphology}

Where coversands are found in the upper part of the trench the Younger Coversand usually constitutes the surface layer. Locally the Older Coversand extends to the surface without any Younger Coversand upon it. The land surface in this type of deposit is characterized by gentle slopes and an elevation of between $0.5 \mathrm{~m}$ and 1.0 $\mathrm{m}$ over 20 to 100 meters of surface is fairly common.

\section{Stratigraphy}

The Older Coversand rests upon a layer of windfaceted and polished pebbles and small stones

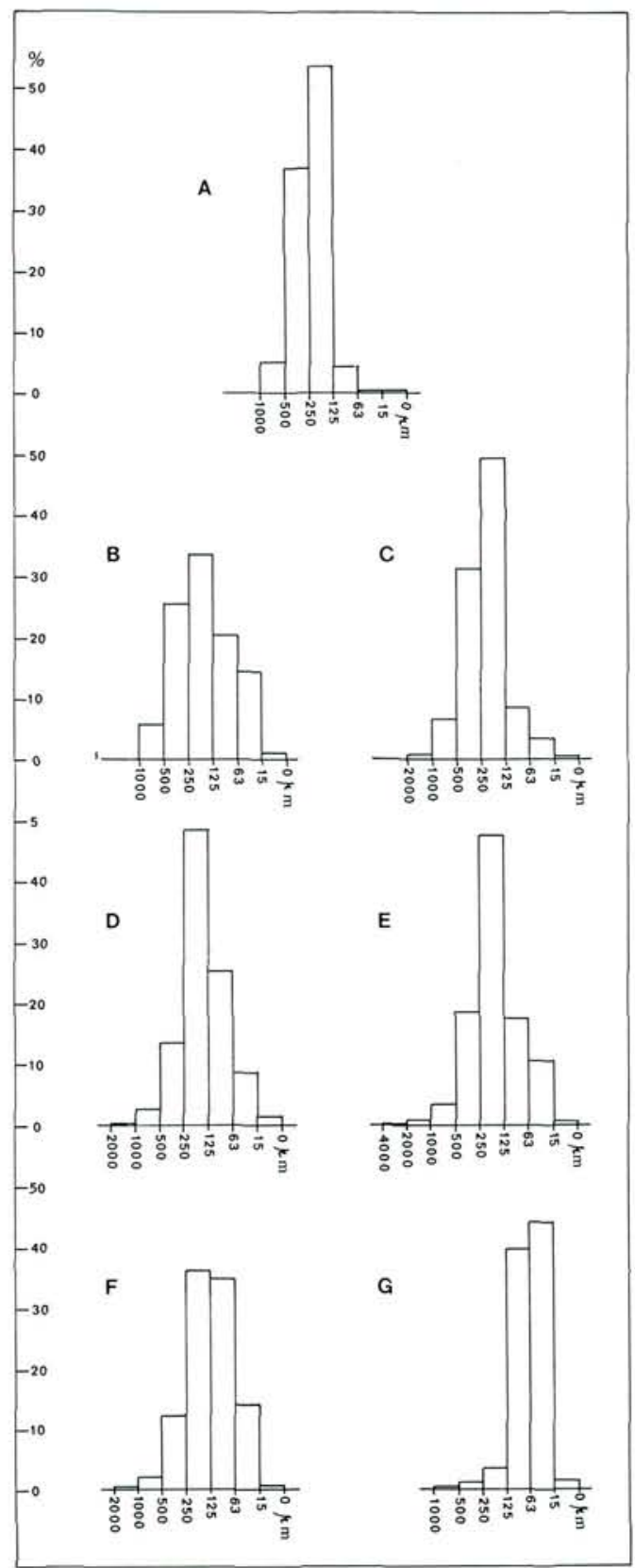

Fig. 6. Histograms showing the grain-size distributions of $A$ : Younger Coversand at km 2.590; B, C, D, E, and F: Older Coversand at km's $2.600,3.560,8.715,10.245$, and 11.860 respectively; and G: Strongly loamy sand in the Older Coversand at $\mathrm{km} 12.170$. 

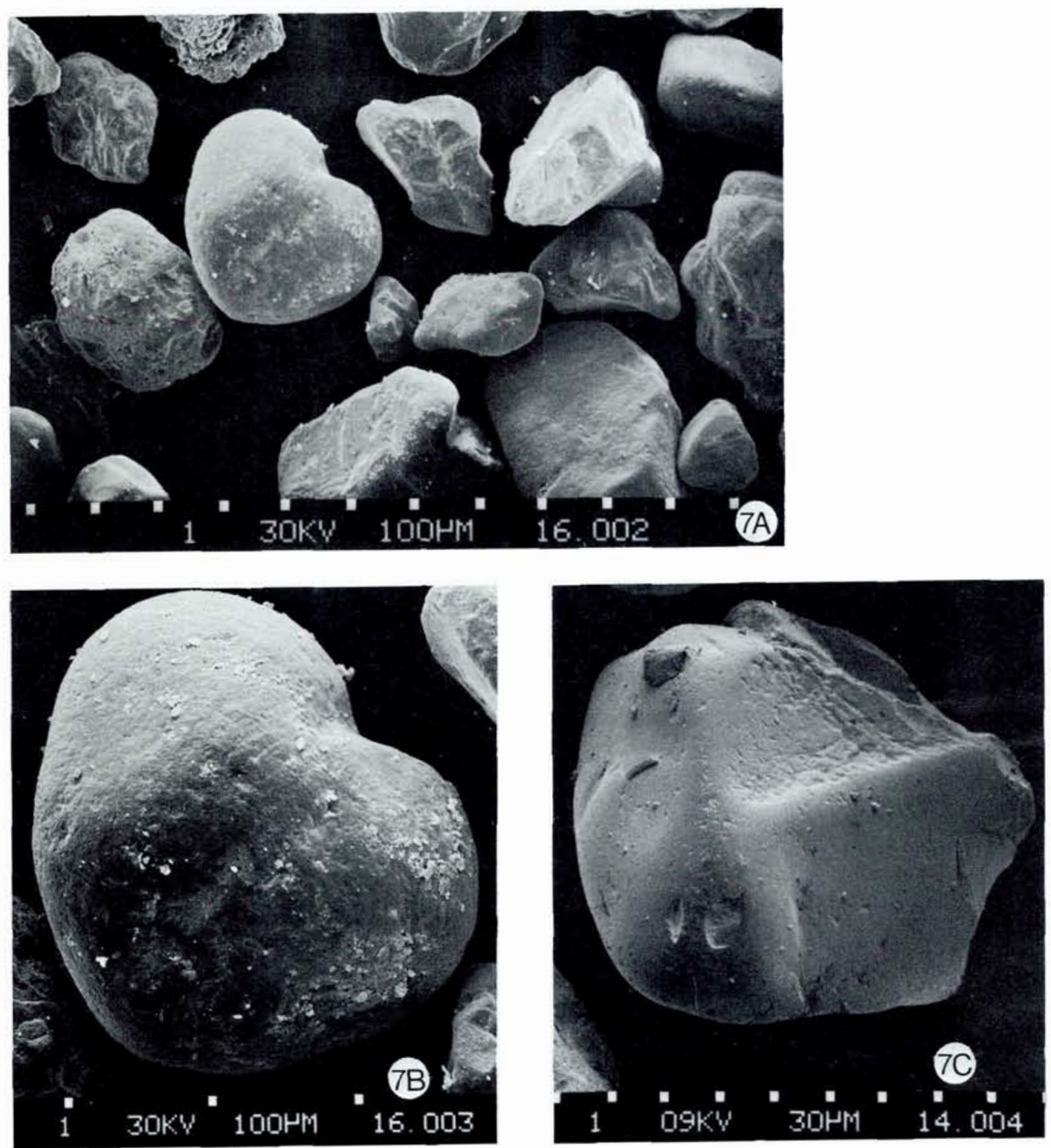

Fig. 7. Scanning electron microscope photograph of the sand grains of a typical coversand sample (A) together with S.E.M. photographs of a single well-rounded (B) and a single sub-rounded sand grain (C).

which in turn rests upon a strongly involuted sequence of sediments. It is overlain either by a fine-grained layer which has been altered by surface processes or it passes gradually into the Younger Coversand which locally contains a bioturbated zone.

This lithological sequence is identical to sequences found in The Netherlands (e.g. van der
Hammen 1951; Wijmstra \& Schreve-Brinkman 1971; Wijmstra \& de Vin 1971; Maréchal \& Maarleveld 1955), Belgium (e.g. Maréchal \& Maarleveld 1955; Heyse 1975), and northern Germany (e.g. Dücker \& Maarleveld 1957).

Studies comparing this type of sequence in The Netherlands, Belgium, and northern Germany conclude that the sequences can not only be li- 
thostratigraphically but also chronostratigraphically correlated between these countries (Dücker \& Maarleveld 1957; Zagwijn \& Paepe 1968). The involutions and the pebble bed underlying the Older Coversand II are of Upper Pleniglacial age (van der Hammen, Maareeveld, Vogel \& Zagwijn 1967). The Older Coversand II was deposited during the Upper Pleniglacial (van der Hammen et al. 1967; Kolstrup 1980). The finegrained layer with mottling which separates the Older Coversand II and the Younger Coversand I represents the Lower Loamy Bed of Bølling age. The Younger Coversand I between the Lower Loamy Bed and the Usselo Soil has become deposited predominantly during the Earlier Dryas. The bioburbated zone between the Younger Coversand I and II, i.e., the Usselo Bed or Soil is of Allerød age. Finally, the Younger Coversand II which rests upon the Usselo Bed is predominantly of Late Dryas age (van der Hammen 1951; Dücker \& Maarleveld 1957; Doppert, Ruegg, van Staalduinen, Zagwijn \& Zandstra 1975; Cleveringa, de Gans, Kolstrup \& Paris 1977). In figure 8 the Dutch stratigraphy is outlined according to van der Hammen (1971).

The striking similarities between the Older Coversands in Denmark and the three above mentioned countries suggest that the Older Coversands were deposited in the same or almost the same environment in the four countries. The same conclusion may be drawn for the Younger Coversands. Furthermore, the identical lithological sequences suggest that changes in environmental conditions were similar in succession in all four countries. It is possble, therefore, that the chronostratigraphic correlation between Belgium, The Netherlands, and Germany might be extended into Denmark, but pollen analysis and

\begin{tabular}{|l|l|l|}
\hline Lithostratigraphical units & \multicolumn{2}{|l|}{ Chronostratigraphical units } \\
\hline Younger Coversand II & Lole Dryas & \\
\hline Usselo Bed or Soil & Allered & \multirow{2}{*}{ Late Glacial } \\
\hline Younger Coversand I & Eorlier Dryas & \\
\hline Lower Loamy Bed & Belling & \\
\hline Older Coversand II & & \multirow{2}{*}{ Pleniglacial } \\
\hline & & \\
& &
\end{tabular}

Fig. 8. Stratigraphical table of the Late-Glacial and the upper part of the Pleniglacial in the Dinkel valley in the Netherlands according to Van der Hammen (1971). radiocarbon dates from the Danish coversands are still lacking. It is hoped that further studies will add more information.

\section{Conclusions}

It has long been known that aeolian deposits are present in parts of southern Jutland (Hansen 1965; Milthers 1925) and Sørensen (1972) briefly mentions coversands. The continuous excavations for the gas pipeline provide a unique opportunity to study the lateral extension of various layers, the stratigraphy of single localities, and the transitions between layers. It is now possible to identify the aeolian deposits and their stratigraphical succession. Both Older and Younger Coversands are represented in southern Jutland and the lateral extension of these deposits within northwestern Europe can thus be extended from the coversand areas in Belgium, The Netherlands, and northern Germany northward into Denmark.

Acknowledgements. We wish to express our gratitude to $P$. Cleveringa (Haarlem) and H. M. French (Ottawa) for their critical perusal of the manuscript. $H$. M. French also improved the English text. The Danish Oil and Natural Gas Company A/S (D.O.N.G. A/S) kindly gave permission to follow the trenching. The Geological Survey of Denmark, The Danish Natural Science Research Council (S.N.F.), and the National Agency for the Protection of Nature, Monuments, and Sites (Fredningsstyrelsen) financed the investigation. The photographical work of I. and C. Torres (Geological Survey of Denmark) and the S.E.M. work of H. S. Hansen and J. Fuglsang Nielsen (Geological Institute, Copenhagen) is gratefully acknowledged. Finally we wish to thank all the people working on the gas pipeline trench for their help and for making the field period a most pleasant time.

\section{Dansk sammendrag}

Under udgravningen til naturgasledningen i Sønderjylland blev der i den nasten $2 \mathrm{~m}$ dybe rende fundet acoliske sedimenter af ældre og yngre dæksandstype over adskillige kilometer. Denne artikel beskriver dæksandenes udseende og egenskaber $i$ de sydligste $13 \mathrm{~km}$ af traceet.

Lithostratigrafien i dxksandsområderne i denne del af Danmark er identisk med den, der findes $\mathrm{i}$ dæksandsområderne $\mathbf{i}$ Holland, Belgien og det nordlige Tyskland. Nederst findes et involueret sediment med en horisont af vindpolerede sten $i$ toppen. Derover findes ældre dæksand overlejret af yngre dæksand. Mellem ældre og yngre daksand findes lokalt en bioturberet zone, og enkelte steder er yngre dxksand opdelt i to lag adskilt af en bioturberet horisont. Formodentligt er den miljømæssige udvikling i de fire lande forlobet parallelt. 


\section{References}

Cleveringa, P., de Gans, W., Kolstrup, E. \& Paris, F. P. 1977: Vegetational and climatic developments during the Late-Glacial and the carly Holocene and aeolian sedimentation as recorded in the Uteringsveen (Drente, The Netherlands). Geologie Mijnb., 56 (3), 234-242.

Doppert, J. W. C., Ruegg, G. H. J., van Staalduinen, C. J., Zagwijn, W. H. \& Zandstra, J. G. 1975: Formaties van het Kwartair en Boven-Tertiair in Nederland. In: W. H. Zagwijn \& C. J. van Staalduinen (eds.) Toelichting bij geologische overzichtskaarten van Nederland. Rijks Geologische Dienst, Haarlem, 11-56.

Dücker, A. \& Maarleveld, G. C. 1957: Hoch- und spätglaziale äolische Sande in Nordwestdeutschland und in den Niederlanden. Geol. Jb., 73, 215-234.

Hansen, S. 1965: Kortbladet Tinglev. Danm. geol. Unders., I, $23 \mathrm{~A}$.

Heyse, 1. 1975: Bijdrage tot de geomorfologische kennis van het noordwestelijk deel van de Vlaamse Vallei en haar randgebieden. Non-published Thesis, Rijksuniversiteit Gent, Fac. Wetensch.

Kolstrup, E. 1980: Climate and stratigraphy in northwestern Europe between 30.000 B.P. and 13.000 B.P., with special reference to the Netherlands. Meded. Rijks Geol. Dienst, 32-15, 181-253.

Maréchal, R. \& Maarleveld, G. C. 1955: L'extension des phénomènes périglaciaires en Belgique et aux Pays-Bas. Meded. geol. Sticht., N.S. 8, 77-86.

Milthers, V. 1925: Kortbladet Bække, 1:100.000. Danm. geol. Unders., I, 15.

Sørensen, R. P. 1972: Iagttagelser i jyske indsande. Dansk geol. Foren., Arsskrift 1971, 5-26. van der Hammen, T. 1951: Late-Glacial flora and periglacial phenomena in the Netherlands. Leid. geol. Meded., XVII, 71-183.

van der Hammen, T. 1971: The Upper Quaternary stratigraphy of the Dinkel valley (with an annotated list of radiocarbon dates). In: T. van der Hammen \& T. A. Wijmstra (eds.) The Upper Quaternary of the Dinkel valley. Meded. Rijks Geol. Dienst, N.S. 22, 59-72.

van der Hammen, T., Maarleveld, G. C., Vogel, J. C. \& Zagwijn, W. H. 1967: Stratigraphy, climatic succession and radiocarbon dating of the Last Glacial in The Netherlands. Geologie Mijnb., 46 (3), 79-95.

Wijmstra, T. A. \& Schreve-Brinkman, E. J. 1971: The Lutterzand section. in: T. van der Hammen \& T. A. Wijmstra (eds.) The Upper Quaternary of the Dinkel valley. Meded. Rijks Geol. Dienst, N.S. 22, 87-100.

Wijmstra, T. A. \& de Vin, E. 1971: The new Dinkel canal section. In: T. van der Hammen \& T. A. Wijmstra (eds.) The Upper Quaternary of the Dinkel valley. Meded. Rijks Geol. Dienst, N.S. 22, 101-130.

Wijmstra, T. A., Schreve-Brinkman, E. J. \& de Vin, E. 1971: Some data on the sedimentology of the Dinkel valley. In: T. van der Hammen \& T. A. Wijmstra (eds.) The Upper Quaternary of the Dinkel valley. Meded. Rijks Geol. Dienst, N.S. 22, 141-146.

Woldstedt, P. \& Duphorn, K.1974; Norddeutschland und angrenzende Gebiete im Eiszeitalter. K. F. Koehler, Stuttgart, $500 \mathrm{pp}$.

Zagwijn, W. \& Paepe, R. 1968: Die Stratigraphie der weichselzeitlichen Ablagerungen der Niederlande und Belgiens. Eiszeitalter Gegenw., 19, 129-146. 